Francesca Mavilla

https://orcid.org/0000-0003-2037-8329

\title{
PROMOTING AN ARTIST AS AN INTEGRAL PART OF DIPLOMATIC NETWORKING: CHIAPPINO VITELLI AND FEDERICO ZUCCARI AT THE COURT OF QUEEN ELIZABETH I
}

\begin{abstract}
In the field of study on relations between Italy and Flanders in the second half of the sixteenth century, the military leader Gian Luigi, better known as Chiappino, Vitelli (1520-75) deserves special attention. Trusted man of Cosimo I de' Medici and maestro di campo generale of the Spanish armies in Flanders since 1567, he was among the protagonists of the first ten years of the Dutch Revolt.

Based on the identification of new archival documents, this essay aims both to broaden the sphere of investigation and deepen the understanding of the role of Chiappino in cultural exchanges between Florence, the Habsburg's and Elizabeth I's courts. At the same time, it is aimed to draw attention to the political and cultural dynamics in which Chiappino Vitelli's action towards the English Queen is embedded. From the documents, it clearly emerges how Vitelli took advantage of his role to earn the favour of the sovereign and, in addition to his loyalty, he did not hesitate to offer her the most varied of gifts, such as animals, weapons and artists, such as the painter Federico Zuccari, who reached Flanders in 1574. Zuccari's sending to the English court should be interpreted as an attempt by the military leader to gain the favour of Elizabeth I when the support of the courts of Florence and Madrid seemed to be lacking, especially after the death of Cosimo de' Medici and the replacement of the Duke of Alba as governor of Flanders.
\end{abstract}

Keywords: Gift, diplomacy, Italy, diplomatic networking, Elizabeth I, Chiappino Vitelli, Federico Zuccari 
Within studies on the connections between Italy and Flanders in the second half of the sixteenth century the figure of the military leader, Gian Luigi, better known as Chiappino Vitelli, is progressively emerging from the oblivion into which he had fallen, to assert himself as a key figure in the years of the birth and affirmation of the Grand Duchy of Tuscany inside the Hapsburg empire. ${ }^{1}$ As Maurizio Arfaioli has pointed out, Vitelli has been victim of the long silence that has affected Italian military history of the modern age. ${ }^{2}$ Together with Ugolino Grifoni from San Miniato, Sforza Almeni from Perugia and the Spaniard Antonio Ramirez de Montalvo, Chiappino was a member of the group of homines novi who gradually surrounded the Duke Cosimo I de' Medici. They were men coming from areas far from Florence, if not directly from territories that were not part of the Principato, and therefore foreign to Florentine politics, but all united by a solid loyalty to the Duke. ${ }^{3}$

Born in 1520 in Città di Castello in Umbria, Chiappino Vitelli proved to be one of the most skilled and trusted members of Cosimo de' Medici's entourage. Captain general of Medici's infantry, Vitelli was appointed Marquis of Cetona in 1558, and later he became the first knight, and

${ }^{1}$ On Chiappino Vitelli (1520-75), see: Famiano Strada, Histoire de la guerre de Flandre (Paris: Antoine de Sommaville 1651), pp. 409, 455-56, 595; Cesare de Laugier, 'Chiappino Vitelli', Giornale militare italiano, 3 (1846), 17-19; Carlo Promis, Biografie di ingegneri militari italiani dal secolo XIV alla metà del XVII (Torino: Fratelli Bocca, 1874), pp. 428-46; Charles van den Heuvel, 'Papiere Bolwerken' de introductie van de Italiaanse steden vestingbouw in de Nederlanden (1540-1609) en het gebruik van tekeningen (Alphen aan den Rijn: Canaletto, 1991), pp. 30-31; Maurizio Arfaioli, 'Alla destra del Duca: la figura di Chiappino Vitelli nel contesto degli affreschi vasariani del Salone dei Cinquecento', Mitteilungen des Kunsthistorischen Institutes in Florenz, 51, no. 1/2 (2008), pp. 271-278; id., 'Sofonisba Anguissola, Francesco de' Medici and Chiappino Vitelli: a lady-in-waiting, a prince and a general at the Spanish court', in The Grand Ducal Medici and their Archive 1537-1743, ed. by Alesio Assonitis, Brian Sandberg (London: Brepols Publishers, 2016), pp. 117-22; Francesca Mavilla, 'Committenti e collezionisti tra l'Italia e le Fiandre, il ruolo di Paolo e Chiappino Vitelli nel contesto artistico e culturale del Cinquecento' (unpublished doctoral dissertation, Università degli Studi di Perugia, 2016); ead., "“Sua signoria è qua in molta buona riputatione con ciascuno": Chiappino Vitelli e i fratelli Guicciardini', Horti Hesperidum, 8, no. 1 (2018), 321-48.

2 Arfaioli, Alla destra del Duca', p. 271; id., 'Sofonisba Anguissola'.

3 Stefano Calonaci, 'Cosimo I e la corte: percorsi storiografici e alcune riflessioni', Annali Di Storia Di Firenze, 9 (2015), 57-76. 
then constable, of the newly founded Order of Santo Stefano. The real turning point in Vitelli's career came in 1567, when he was sent by Cosimo de' Medici to Flanders to serve king Philip II as maestro di campo generale of the Spanish armies following the Duke of Alba, Fernando Alvarez de Toledo. It was the sovereign himself who asked for Vitelli's collaboration, as shown in a letter, previously unpublished, preserved in the State Archives of Florence, dated 12 February 1567 and addressed to:

Illustre y bien amado nostro, ya avreis entendido la determinacion que he tornado de yr en persona à Flandes, con exercito, para allanar las desordenes y alteraciones que en algunas de a quellas tierras han succedido, y conservar la entera obediencia que se me deve, y porque por ser la jornada de tal calidad, y enque tanto me va, desseo que os helleis y me sirvais en ella, por la buena opinion en que os tengo, y escrivò y embio a rogar al Duque y al Principe de Florencia que lo tengan por bien, como tiengo por cierto que lo haran, a vos os encargo mucho, que luego que os ayan dado licentia, os dispongais a tomar este trabajo, y vais a Genova, y espereis alli al Duque de Alva, mi Mayordomo mayor y Capitan General, que partira de aqui dentro de pocos dias, y hareis lo que el os ordenare, que de a quello sere yo muy servido y terne con vostra persona la cuenta que meresceis. ${ }^{4}$

From 1567, Vitelli became one of the protagonists of the first ten years of the Dutch Revolt, ${ }^{5}$ not returning to Italy, dying on 3 November 1575 from wounds incurred at the siege of Zieriksee in Zeeland. ${ }^{6}$

4 Florence, Archivio di Stato (hereafter cited as ASFi), Rondinelli Vitelli, b. 1 ins. 5, fol. 67: 'Illustrious and beloved, you have already understood the determination that I have taken to go to Flanders in person, with exercise, to settle the disorders and alterations that have occurred in some of those lands, and to preserve all the obedience that is due to me, and since the journey is of such quality, and since it suits me so well, I wish you to relax and serve me in it, for the good opinion in which I hold you, and I wrote and begged the Duke and the Prince of Florence to take it in hand, as I am sure they will, and I entrust you with this task, after you have been given your leave, to go to Genoa, and wait there for the Duke of Alva, my Mayordomo mayor and captain general, who will leave from here in a few days, and do as he commands, because I will be very well served, and I will finish with you the amount you deserve'. The same day Philip II wrote a letter to Cosimo de' Medici to ask for Chiappino's service. Adalid Nievas Rojas, 'Nuevos datos para la biografía de Francisco de Aldana (II). Primera etapa en Flandes (1567-1571)', Boletín de la Real Academia Española, 100, no. 321 (2020), 147-206 (p. 170).

5 See for example Strada, pp. 409, 455-56, 595.

6 Florence, Biblioteca Moreniana, Fondo Moreni, MS 28, fol. 145, Lorenzo Borghesi, Vita di Chiappino Vitelli (hereafter cited as Borghesi, Vita Vitelli). 
Despite his considerable resume, the cultural role of Vitelli is still little investigated. His several letters, sent from his various missions, are a valuable source to understand his contribution to the circulation of news, information and works of art, first in Italy, and then between the Peninsula and the courts of Madrid and Brussels. In his correspondence, Vitelli not only referred to current historical events, but attached to his letters maps and drawings; gave advice; asked for favours and sent gifts, including portraits, medals, coins, crystals, also plants, fruits and hunting animals.

For the Medici state of the sixteenth century, so intent as it was on preserving its ties with the Habsburgs, but equally determined not to be crushed by imperial politics, it became fundamental to acquire real-time information on the Italian and European political situation to maintain the balance to guarantee its existence. From this point of view a personality like Vitelli's grew increasingly in importance because, during his career, and especially after 1567 , he became not only one of the significant members of Cosimo's alliance policy regarding Philip II, but was a point of reference for the Italians residing in Flanders. Merchants, like the brothers Lodovico and Giovan Battista Guicciardini, bankers and condottieri often addressed him to intercede on their behalf with the Grand Duke. In the same way, he appealed to them to request favours or loans for himself or for the Grand Dukes, Cosimo and, then Francesco. ${ }^{7}$ In the years spent between his residences in Brussels and Antwerp, Vitelli became, besides a commander, almost a diplomat, a sort of cultural mediator.

Some studies have already highlighted Vitelli's ability to understand the interest in Italian art and culture in Madrid, which led him to reinforce the links between the Medici and Hapsburg courts. ${ }^{8}$

Through the identification of new archival documents, this article will extend the scrutiny and deepen the understanding of the role of the military leader in the cultural exchanges between Florence, the Habsburg courts and that of Elizabeth. At the same time, it will analyse the political dynamics within which Chiappino Vitelli's actions towards

7 Mavilla, 'Sua signoria', pp. 321-48.

8 Mavilla, 'Committenti', pp. 221-34; Arfaioli, 'Sofonisba Anguissola', pp. 117-22. 
Queen Elizabeth were embedded. In the following text, we will see that to earn the favour of the sovereign and her court, Vitelli did not hesitate to offer, in addition to his loyalty, the most varied of gifts such as animals, rumours about weapons and finally artists, such as the painter, Federico Zuccari. In the sixteenth century, the complicated relations between the English court and Florence had prevented the latter from gaining accreditation for a resident. Religious and political differences, with the presence in London of many Florentines linked to fuoriuscitismo, had made relations between these two countries unstable. At the same time, the Medici dynasty had managed to organise an efficient network of collaborators and informers in Florence's pay, who could tell what was happening in Elizabeth's kingdom. ${ }^{9}$ Vitelli's action was part of this cultural framework and, as we will see, he was able to exploit these links to adapt them to his needs skilfully.

\section{A COMPLEX STORY: THE FIRST CONTACTS BETWEEN VITELLI AND THE ENGLISH COURT}

In his recent noteworthy edition of Elizabeth I's Italian letters, Carlo Maria Bajetta has published two letters from the sovereign to Chiappino Vitelli. ${ }^{10}$ These missives, dated 2 March 1571 and 3 August 1575, describe two different moments in the contact between the Queen and the Italian condottiero in the framework of the cultural milieu of the court. The letters to Vitelli reveal a wider context in which the Italian soldier turns from being an important intermediary between the Grand Duchy of Tuscany and the English crown to trying to earn, individually, the personal favour of the sovereign and of her favourites.

The first letter was sent shortly after the end of Chiappino's journey to the English court in 1569 . Given his language skills, ${ }^{11}$ he was sent by

9 Alessandra Contini, 'Aspects of Medicean Diplomacy in the sixteenth century', Politics and Diplomacy in Early Moderm Italy. The Structure of Diplomatic Practice, 1450-1800, ed. by Daniela Frigo (Cambridge: Cambridge University Press, 2000), pp. 49-94.

${ }^{10}$ Carlo Maria Bajetta, Elizabeth I's Italian Letters (New York: Palgrave Macmillan, 2017).

${ }^{11}$ In Vitelli's biography by don Lorenzo Borghesi, we read that he studied Latin and Greek, but also Spanish and English; Borghesi, Vita Vitelli, fols 20-21. 
the Duke of Alba to England to negotiate the restitution of a considerable sum of money bound for Flanders which had been seized by the English. ${ }^{12}$ The sending of Vitelli had been agreed with the Duke of Alba who, unlike the sovereign Philip II, was leaning towards a softer approach with the English crown, in order not to compromise the commercial connections between the Netherlands and England. ${ }^{13}$ This is demonstrated by the fact that only a few months before, on 21 July 1569, Chiappino had written to Florence who, in agreement with the Duke of Alba, had sent Stiatta Cavalcanti to the English court with the excuse of checking some of his trade, so that, through his brother Guido, a Florentine merchant and semi-official Italian diplomat near the Queen, ${ }^{14}$ he could penetrate the real intentions of Elizabeth. ${ }^{15}$ This was probably unsuccessful, and Chiappino decided to leave for England himself. He arrived in Dover on 15 October and, after being forced to leave much of his retinue in the English port, proceeded to London accompanied by just his closest companions including his secretary, Sestilio Valenti and the Spanish poet and diplomat, Francisco de Aldana. ${ }^{16}$ Once in London, not only did Chiappino discuss the question of Spanish ships with Elizabeth but also engaged in long conversations on art with Elizabeth's favourite, Robert Dudley, Earl of Leicester. ${ }^{17}$

Around the end of November, however, when Vitelli was about to return to the Netherlands, rumours began to circulate about the

12 Henry Kamen, Il duca d'Alba (Torino: Utet, 2006), pp. 121-22; Bajetta, Elizabeth I's Italian Letters, pp. 63-64.

13 Geoffrey Parker, 'The Place of Tudor England in the Messianic Vision of Philip II of Spain: The Prothero Lecture', Transactions of Royal Historical Society, 12 (2002), 167-221 (pp. 188-89).

${ }_{14}$ Michael Wyatt, The Italian encounter with Tudor England: a cultural politics of translation (Cambridge: Cambridge University Press, 2005), pp. 140-42.

15 ASFi, Mediceo del Principato (hereafter cited as MdP), vol. 650, fol. 109. For more about the relations between Vitelli and Cavalcanti, see: Mavilla, 'Sua signoria', p. 331 .

16 Miguel Ángel de Bunes Ibarra - Abraham Madroñal, 'Una carta jocosa inédita de Francisco de Aldana y nuevos datos parasu biografía', Revista de Filología Española, 90, no. 1 (2010), 9-45. On Francisco de Aldana and his relationship with Chiappino Vitelli I underline the fundamental and recent study by Nievas Rojas, pp. 147-206.

17 George Daniel Ramsay, The Queen's Merchants and the Revolt of the Netherlands (Manchester: Manchester University Press, 1986), pp. 154-57. 
contribution of the Spanish government to the Northern Rebellion. In December, Alba ordered Vitelli to leave and, shortly after, Elizabeth, suspicious about his possible involvement, insisted Vitelli leave English soil, ${ }^{18}$ through sending him the diplomat Henry Cobahm. ${ }^{19}$ Vitelli was forced to speed up his departure, much to the displeasure of Leicester. ${ }^{20}$

Back in Brussels on 2 January 1570, ${ }^{21}$ Vitelli did not wait long before trying to reconnect with the English crown. Taking advantage of the presence in the Netherlands of Henry Cobham, who arrived in August to pay homage to the new wife of Philip II and to resume negotiations for a marriage between Elizabeth and Charles of Austria, Vitelli expressed his desire to reconnect with Elizabeth, offering 'any favour for Her Majesty's sake'. ${ }^{22}$ This was followed by words in favour of Vitelli from Guido Cavalcanti, who, in a letter to Cecil and Mildmay, offered to go to the Netherlands to continue negotiations with the government but he suggested to write a letter to Chiappino Vitelli first. ${ }^{23}$

Vitelli was apparently acting as a man of peace, and after Cobham's return in England, the Queen was persuaded to write to the Marquess on 2 March 1571. This letter, published by Bajetta, shows that the Queen was open to peace - so difficult to maintain with Spain in this period.

At the end of 1571, there was still discussion of the mysterious participation of Vitelli in the failed Ridolfi plot. ${ }^{24}$ Vitelli was suspected of

18 Bajetta, Elizabeth I's Italian Letters, p. 63.

19 In a letter from from Brussels to Florence, 22 January 1570 Vitelli says that, while waiting the resolution of the Rebellion, he spoke with the Queen who told him she had never suspected him but it was all the fault of the "popolazzo", the "people". Florence, ASFi, MdP, vol. 650, fols 160r-v, 168r-v.

${ }^{20}$ A notice from Flanders on 27 December says that Leicester gave Vitelli two horses to show displeasure at his sudden departure. Letters relating to Chiappino's journey to England from his arrival to his leave can be found in Constantin Kervin de Lettenhove, Relations Politiques des Pays-Bas Et de l'Angleterre, Sous le Règne de Philippe II (Brussels: Hayez, 1886), vol. 5, pp. 463, 466-74, 476-78, 480-84, 486-98, 500-10, 512-23, 530-37, 541-43, 546-60, 563-82.

21 ASFi, MdP, vol. 650, fols 159r-v.

22 Carlo Maria Bajetta, 'Elizabeth I, Chiappino Vitelli and Federico Zuccaro', Notes and Queries, 60 (2013), 386-91 (p. 387).

${ }^{23}$ Ibid., pp. 388-89.

24 The Florentine merchant, member of the Catholic resistance, was also in those years the Pope's secret nuncio in London but, after the failure of his plan, was expelled 
having been involved in the plot, to the extent that some believed he had volunteered, in talks with Ridolfi, to assassinate Elizabeth. According to the plans of the Florentine merchant, an army led by the Duke of Alba should have invaded the east of England and thus provoke an uprising of the English Catholics who, after the capture of Elizabeth, would have placed on the throne the Catholic, Mary Stuart, together with the Duke of Norfolk, who was to become her consort. To obtain the support of the Pope and King Philip, Ridolf first met Pius V in Rome and then, on 17 July, reached the court of Madrid. His arrival, signalled by the Florentine ambassador Leonardo de Nobilii, ${ }^{25}$ was intended to ask for the support of the sovereign and Alba. In Madrid, Ridolfi was joined in August by Vitelli, who arrived at court to update the king on the government of the Netherlands. ${ }^{26}$ Vitelli had known Ridolfi for a long time and often used him to send letters to Florence. ${ }^{27}$ Still, it is not clear whether he was really willing to collaborate in his plan or instead preferred to hesitate, as did the Duke of Alba, given the feasibility of the plot. ${ }^{28}$ Finally, Elizabeth became aware of the conspiracy: the Duke

from the capital and continued to serve the Medici family in Spain and Portugal; Anna Maria Crinò, 'Un altro memoriale inedito di Roberto Ridolfi', La Bibliofilia, 57 (1955), 148-155; Francis Edwards, The Marvellous Chance Thomas Howard, fourth duke of Norfolk and the Ridolphi plot, 1570-1572 (London: Hart Devis, 1968); Wyatt, pp. 145-46.

25 ASFi, MdP, vol. 4903, Letter from Madrid to Florence, 17 July 1571.

26 Ibid., Letter from Madrid to Florence, 24 August 1571. Nobili wrote to Florence: 'il signor Chiappino è stato ricevuto dal re et da questi signori con gran caresse et negotia con gran reputatione' ('Lord Chiappino has been received by the King and by these men with great honour and he deals with big reputation').

27 ASFi, MdP, vol. 649, fol. 80, Letters from Brussels to Florence, 12 October 1567; and ASFi, MdP, vol. 650, fol. 346.

${ }_{28}$ ASFi, MdP, vol. 4903, Letter from Madrid to Florence, 24 August 1571; Nobili wrote that Chiappino was forced to leave for Flanders even if 'per tutto dicembre vuole essere in Italia in ogni modo' ('for the whole of December he wants to be in Italy anyway'), but at court they don't want to let him go and 'le carezze fatteli dal re, et da tutti sono state straordinarie, la riputatione con che è partito è grande, la confidenza che mostrano in lui è la maggior di qualsivoglia italiano et forse spagnuolo' ('The homages given to him by the king, and by all of them were extraordinary, the reputation with which he departed is great, the trust they show in him is greater than any Italian, and perhaps Spanish'). In a part of the encrypted and decoded letter we read that Ridolfi claimed that Chiappino supported his project while on his part the Vitelli answered 
of Norfolk was arrested, tried and executed. In his letters to Florence, often in cypher, ${ }^{29}$ Vitelli showed that he was up to date on the trial of the English nobleman and communicated to Francesco de' Medici the death of Norfolk on 2 June $1572 .{ }^{30}$ Indeed, even if he did not support him personally, de' Medici looked positively on the conspiracy, so much so that, after being exiled, Roberto Ridolfi became a trusted man of the Medici. ${ }^{31}$

\section{CHIAPPINO VITELLI'S NEW ATTEMPT TO RAPPROCHEMENT WITH THE ENGLISH COURT}

Three years after the plot, the political situation had changed for Vitelli. Cosimo de' Medici died in 1574, the year before the Duke of Alba was replaced as governor of Flanders by Don Luis de Requésens, and Vitelli feared that he would no longer enjoy the same support at the courts of Florence and Madrid. From the letters sent from Flanders to Francesco I, to the secretary Concini and to the Duke of Alba in those years, Vitelli several times indicated a desire to return to Florence. However, all of them asked him to stall. ${ }^{32}$ That is probably why, in 1575, Vitelli tried again to approach the English court. It is not clear whether he was really asking to retire from his military career or, as Bajetta suggests, he was looking for a 'fresh employment', ${ }^{33}$ maybe seeking a new opportunity in England.

In February 1575, Vitelli had addressed a letter to his old friend Robert Dudley, informing him that he was about to send him a man

Nobili's questions in an ambiguous way, mentioning the many rumors that were circulating in Germany because of the Flemish escaped there.

29 ASFi, MdP, vol. 650, fol. 348r; ibid., vol. 651, fols 1r-v.

30 ASFi, MdP, vol. 651, fols 11-13v, 49r-v, Letter from Brussels to Florence,

21 February 1572. On Ridolfi plot see Parker, pp. 189-207, 219-21.

31 Contini, pp. 89-90.

32 In a letter from Bruxelles to Concini in Florence, on 29 [...] 1572, Vitelli writes that Alba had tried to convince him to remain by telling him that the Sovereign had preferred him to John of Austria and Ascanio della Corgna but Chiappino concludes by saying: 'li giorni mi mancano, et la gotta mi minaccia et io vorrei finir i miei in servizio di iddio, con satisfattione dei nostri padroni' ('the days I miss, and gout threatens me, and I would like to end my days in God's service with satisfaction of our leaders'), ASFi, MdP, vol. 651, fols 82-85r.

33 Bajetta, Elizabeth I's Italian Letters, p. 69. 
who possessed 'the secret of steel hardening to make it ball proof'. ${ }^{34}$ Understandably, Vitelli first leveraged his role as a military expert, which probably, had not the desired success and he decided to change his approach, taking advantage of the presence in Flanders of the painter Federico Zuccari.

The painter's short stay in Antwerp is described by his biographers thus: 'Federico all'hora andò in Fiandra' and there he stayed for than a few days making some cartoons of tapestries ${ }^{35}$ that, according to Borghini, depicted the Pueritia, or childhood, and Youth. ${ }^{36}$ Zuccari had left the Italian territories on September 1573 to go to Paris in the wake of Cardinal Carlo di Guisa but, on the death of his patron on 25 December 1574, he had to leave France ${ }^{37}$ for Flanders. His biographers do not report the reason for this trip to Flanders. Still, but he was undoubtedly able to deepen his interest in Flemish art which had already been shown in the drawings taken from the Grimani breviary. ${ }^{38}$ Some factors lead us to suppose that after leaving France, in the first months of 1575, he was welcomed in Antwerp by Chiappino Vitelli, who was forced to remain at his house because of worsening gout. ${ }^{39}$ The reasons that led the painter from Sant'Angelo in Vado to rely on Vitelli cannot just be due to their common geographical origins, ${ }^{40}$ but is more likely that, as Acidini claims, Vitelli was mindful of Zuccari's commitment in the decorative apparatus for the wedding between Francesco de' Medici and

${ }^{34}$ Bajetta, 'Elizabeth I, Chiappino Vitelli', p. 4.

35 Giovanni Baglione, Le vite de pittori, scultori et architetti. Dal Pontificato di Gregorio XIII del 1572 in fino a' tempi di Papa Urbano VIII nel 1642 (Rome: Andrea Fei, 1642), p. 123.

36 Raffaello Borghini, Il Riposo (Florence: Marescotti, 1584), p. 573; Cristina Acidini, Taddeo e Federico Zuccari fratelli pittori del Cinquecento (Milan: Jandi Sapi, 1998), vol. 2, p. 63.

37 The cardinal died in Avignon on 25 December 1574. Acidini, vol. 2, p. 53.

38 Martina Lorenzoni, 'Federico Zuccari e il Breviario Grimani', Saggi e memorie di storia dell'arte, 39 (2015), 7-29, 238.

39 ASFi, MdP, vol. 651, fols 204r-v.

40 Roy Strong claims that Vitelli recommended the painter also for a sort of commonality of origin since Zuccari came from Sant'Angelo in Vado, not far from Città di Castello. Roy Colin Strong, 'Federigo Zuccaro's Visit to England in 1575', Journal of the Warburg and Courtauld Institutes, 22 (1959), 359-60 (p. 359). 
Joanna of Austria in December $1565 .{ }^{41}$ In addition, Vitelli had known Cardinal Charles of Lorraine or Guise, Zuccari's patron, since $1549 .{ }^{42}$ It is possible, therefore, that Vitelli had remained in contact with the cardinal, thus facilitating the passage of Zuccari.

Shortly after Zuccari's arrival in Antwerp, Vitelli attempted an approach to the English crown by sending the painter to the court. On 15 March 1575, the painter left for England with a letter of introduction as 'one of the most excellent and eminent painters to be found in Italy' signed by Chiappino Vitelli. ${ }^{43}$ The letter was probably addressed to Robert Dudley, a longstanding contact of Vitelli. Archival evidence shows that Vitelli was well aware of the closeness between the Queen and Leicester and their probable 'casamento'. ${ }^{44}$ This was probably the reason that Zuccari made two full-length portraits for the Queen and Leicester, of which two drawings, inscribed and dated on verso in the artist's hand, remain at the British Museum. ${ }^{45}$ These portraits, as has been suggested, were quite likely meant to be unveiled in the course of the Queen's visit to Kenilworth in July $1575 .{ }^{46}$

41 Acidini, vol. 2, p. 56.

42 ASFi, MdP, vol. 1175, Letter from Livorno to Florence, 9 December 1549. Tommaso di Iacopo de' Medici wrote to Pier Francesco Riccio on the arrival in Livorno of five French galleys, with Carlo di Guisa on board, and that Cosimo had sent Chiappino Vitelli to welcome them.

43 Strong, pp. 359-60. The letter may have been written, as often happened, by the secretary of Vitelli, Sestilio Valenti, for Strong's own statement that only the last line with the greeting formula and the signature belong to Vitelli.

${ }_{44}$ ASFi, MdP, vol. 651, fols 49r-v, Letter from Brussels to Florence, 21 April 1572. Vitelli wrote: '[La regina Elisabetta] ha ordinato il parlamento generale che suol fare in quel Regno dove dicano si farà l'ultimo sforzo per haver il consenso di poter effettuare il casamento tra lei e il conte di Leister [...]' (Queen Elizabeth] has ordered the general parliament to do what they do in that Kingdom where they say the last effort will be made to have the consent to be able to do the marriage between her and the Count of Leicester [...]'.

45 John Arthur Gere, Philip Pouncey, Italian Drawings in the British Museum, Artists Working in Rome (London: Trustees of the British Museum, 1983), pp. 300-01.

46 Albert Charles Sewter, 'Queen Elizabeth at Kenilworth', Burlington Magazine, 76, no. 444 (1940), 73-73+75-76; Elizabeth Goldring, 'Portraits of Queen Elizabeth I and the Earl of Leicester for Kenilworth Castle', Burlington Magazine, 147 (2005), 654-60. 
The link between Vitelli and Leicester may have been through Thomas Wilson, ambassador to Flanders of the English crown from November 1574 to 30 March 1575, who was a long-time friend of Leicester. In January 1575, Vitelli had spoken to Wilson about his desire to obtain a licence to return to Italy, also expressing his willingness to waive his Spanish crown salary. ${ }^{47}$ The ambassador may have had communication with the court and the received information from Vitelli so that the Queen herself wrote a letter from Richmond on 16 February, which has remained unknown until now, to thank the military leader:

Al molto honorato et illustre signore, il signor Chiappino Vitelli Marchese di Cetona e amico nostro charissimo. Signor marchese honorato, non senza grandissimo piacere et contentezza dell'animo nostro il Dottore Wilson servitor nostro il quale per le faccende nostre ne i Bassi Paesi del Re Catholico charissimo nostro fratello per hora si ritrova ci ha fatto intendere i molti lodevoli et buoni ufficii molte volte fatte da v[ostra] s[ignoria] per la sincera et calda sua divotione verso di noi, et la buona voluntà indirizzata sempre alla grand lode et honor del nome nostro, cosa veramente d'uno nobil cuore degna mostrarsi in tutti i casi cortese et gentile, rasserenando più presto con bel modo le cose turbide che con prattiche procurando nuove tempestà. Non havemo perciò potuto per adesso far altro, che con queste lettere ingenuamente testificare, quanto cotesti vostri portamenti ci hanno dati tra tutti honore et oppresso di noi gratia, de quali et d'altri vostri ufficii et cortesie verso di noi dimostrate quelle gratie ne rendiamo che per noi si possono le maggiori promettendovi, signor marchese, della parte nostra in ogni cosa tutto quello favore che la vera nostra virtù et valore ci pare con giustissima ragione haver meritata. Restiamo però sommamente desiderose che qualche tale cosa ne i nostri paesi si ritrovasse della quale potessimo dello animo nostro inverso di voi fare scambievole dimostranza.

State sano.

Di Pallazzo nostro Richmondia [Richmond] a gli 16 di febraro 1574 [n/s.1575] ${ }^{48}$

47 De Lettenhove, p. 409. The information is confirmed by a letter from Vitelli from Brussels to Concini in Florence, 22 December 1574, ASFi, MdP, vol. 651, fols 296-297v.

48 ASFi, Rondinelli Vitelli, b. 1, ins. 5, fol. 220, Letter from Richmond to Brussels, 16 February 1575: in translation: 'To the very honoured and illustrious lord, Sir Chiappino Vitelli, Marquis of Cetona and our most charming friend. Honourable Marquis, not without great pleasure and contentment of soul, our servant Doctor Wilson, who is now for our business in the Netherlands of Catholic King our brother, has made us understand the very praiseworthy and good offices often made by you, for your sincere and warm devotion towards us and your good will always addressed 
This document not only testifies to the dealings between the Queen and Vitelli but also indicates that at the beginning of 1575, in his attempt to bid farewell to his assignment in Flanders, or better, to find a more comfortable assignment, Vitelli sought the support of the English crown.

Shortly after receiving the letter from the Queen, Vitelli informed Wilson that it was his desire to serve Elizabeth as best he could, ${ }^{49}$ and Zuccari's presence in Flanders became a good pretext. The painter stayed at the English court for about six months. During that period he also visited the residence of the Count of Pembroke where, as the biographer van Mander reports, he admired the portrait of Christine of Denmark, Duchess of Milan, by Hans Holbein the Younger. ${ }^{50}$ During his English stay Zuccari copied at least two mural paintings by the German painter, as demonstrated by Zuccari's two drawings at the Kupferstichkabinett in Berlin, taken from the decoration of the Guildhall in London depicting the Triumph of Poverty and the Triumph of Richness, then also translated into engravings. ${ }^{51}$ Zuccari's admiration for Holbein must have been very strong if van Mander reports that years later in a conversation he had with Goltzius in Rome, he called him another 'Raphael'. ${ }^{52}$

Zuccari's stay at the English court, as well as having an influence on his education as a painter, proved him to have been much admired

to the great praise and honour of our name, truly of a noble heart worthy to show itself in all cases courteous and kind, soothing as soon as possible with a beautiful way the turmoil things than with practical procuring new difficulties. For now, therefore, we have not been able to do anything else, other than with these letters ingenuously testify how much your attitude gave us among all honour and grace, of which and of your other offices and courtesies towards us shown those graces we make it possible for us to the greatest by promising you, lord Marquis, of our part in all things, all that favour that our true virtue and value, seems to us with good reason to have deserved. We remain, however, supremely desirous that some such thing might be found in our countries that we might be able to show in exchange for you. Fare well. From our palace Richmond, on 16 February 1575'.

49 De Lettenhove, vol. 7, 1882, p. 456.

50 Elizabeth Goldring, 'An Important Early Picture Collection: The Earl of Pembroke's 1561/62 Inventory and the Provenance of Holbein's 'Christina of Denmark', Burlington Magazine, 144 (2002), 157-60.

51 Acidini, vol. 2, p. 59.

52 Karel van Mander, Le vite degli illustri pittori fiamminghi, olandesi e tedeschi, ed. by Ricardo de Mambro Santos (Sant'Oreste: Apeiron Editori, 2000), p. 173. 
by Elizabeth herself. On 3 August 1575, in a further letter Elizabeth thanked Vitelli for his proven 'devotion and loving kindness' and for having paid homage to her ambassador, Thomas Wilson, who left on 30 March for England, and to the Count of Pembroke. ${ }^{53}$

At this time the interest of the Italian soldier had turned again to Florence. Probably Vitelli was aware, perhaps thanks to Zuccari himself, of the growing tension between the English crown and the Hapsburg kingdom, so much so that he had to dismiss the idea of an assignment across the Channel. That it was Zuccari himself who informed him can be confirmed by the letter sent by Vitelli in July, while the painter was still in England, addressed to Francesco de' Medici in Florence to communicate that 'Messer Federigo Zuchero, painter of Sant'Angelo in Vado, came to these countries last year and is now in England - and - he wants to serve V.A. in the work of the dome and in everything that will be needed'. ${ }^{54}$ Vitelli then proposed Zuccari to de' Medici to finish the decoration of the dome of Santa Maria del Fiore, left incomplete by Vasari. One month later, in view of Zuccari's departure for Italy, Vitelli gave him a second letter for the Prince, dated 30 August 1575, to remind him of his suggestion to hire the painter. ${ }^{55}$ Although Francesco de' Medici accepted Zuccari, as we know, the decoration of the dome was attended by controversy. ${ }^{56}$

In an effort to demonstrate his loyalty to the Medici court and to encourage his return from Flanders, Vitelli tried to get closer to Cosimo's heir with whom relations must have been more complicated. Whether or not Vitelli's attempt could have been successful, we are unable to tell, due to his sudden death in November.

53 During summer 1575, Wilson was in Belgium with his wife who died in Spa; Bajetta, 'Elizabeth I, Chiappino Vitelli', p. 5. A copy of the letter is in ASFi, Rondinelli Vitelli, b. 1, ins. 5, fol. 222.

54 Anna Maria Crinò, 'Documenti relativi a Pietro da Cortona, Ciro Ferri, Pietro Tacca, Pier Maria Baldi, Il Guercino e Federigo Zuccaro', Rivista d'arte, 34 (1959), 151-57 (pp. 156-57).

55 Ibid., p. 157.

56 Diletta Gamberini, 'La “concucia nana” di Federico Zuccari: critica d'arte in versi all'ombra del Giudizio Universale per la cupola di Santa Maria del Fiore', Mitteilungen des Kunsthistorischen Institutes in Florenz, 59, no. 3 (2017), 362-87. 
We now know, however, that Zuccari's stay in Flanders may have had a further consequence for Chiappino Vitelli. In an inventory drawn up at his death, we read that among the paintings, there is a 'portrait of the Queen of England'. ${ }^{57}$ It could be assumed that it is a copy made for him by Federico Zuccari before leaving Antwerp, where he had the opportunity to meet artists such as Frans Floris or Paludanus, and maybe to visit the Plantijn's printing house, but, most of all, to have the first contacts with the Leiden painter Otto van Veen, then his pupil in Rome. ${ }^{58}$

\section{CONCLUSION}

The meetings between Vitelli and Queen Elizabeth echoed widely after his death. In Lorenzo Borghesi's seventeenth-century biography of Vitelli, we can read about the first meeting between the Queen and the Marquess in 1569, when Elizabeth, informed before their encounter on how the Italian diplomat was dressed, decided to wear clothes and accessories matching his, to show him that she knew his ways very well and he did not need to convince her. ${ }^{59}$ Even if Borghesi's text is not always accurate, it is interesting to see in this case how far the narration goes to outline the impression that this encounter with the English Queen had in the memory of Vitelli or of someone very close to him, who probably transcribed this event in notes that later were used as a source for his biographer. ${ }^{60}$ The same information could have been used to draft the theatrical play by Francesco Ignazio Lazzari, printed in Città di Castello in 1669, entitled The triumph of the Catholic religion in England, written on the occasion of the opening of the city theatre on the initiative of an academy led, not by coincidence, by Girolama Bandini Vitelli. ${ }^{61}$

57 San Giustino, Archivio Bufalini, degli Azzi, b. 140, ins. 5, fol. 18.

58 Acidini, vol. 2, pp. 57, 99-100.

59 Borghesi, Vita Vitelli, fols 133-36; Bajetta, 'Elizabeth I, Chiappino Vitelli', p. 5.

60 Borghesi, Vita Vitelli, fol. 241.

61 Francesco Ignazio Lazzari, Il trionfo della religione cattolica nell'Inghilterra opera scenica del signor Francesco Ignatio Lazzari Accademico Illuminato di Città di Castello (Forlì: Saporetti, 1669); Galliano Ciliberti, Il Teatro degli Accademici Illuminati di Città di Castello (Firenze: Olschki, 1995), pp. 25, 69-71. 
This new archival evidence shows that Vitelli's action in favour of Zuccari was not isolated, but was part of an overall project for the rapprochement to the English crown after the tensions generated in previous years. Later, he exploited Zuccari's presence to strengthen ties with the Tuscan duchy, in view of a more favourable relocation on the political scene. Using his diplomatic skills, Chiappino Vitelli encouraged the circulation between Italy, Flanders and England not only of news but also of artists such as Federico Zuccari. Thanks to his eclectic personality, Vitelli demonstrated his ability to perceive political changes and exploited the English court's interest in Italian art for his own purposes. At the same time, even though he was far from Florence and the Medici court, Vitelli understood that a way to approach Francesco I could be to suggest an artist like Zuccari, willing to complete work as fundamental to the Florentines as the dome of Santa Maria del Fiore. It remains to be seen how much Zuccari was aware of his role in aiding Vitelli or how much his activity undertaken beyond the Alps is due to his personal initiative. What is certain is that the sudden death of Vitelli abruptly interrupted these contacts and it does not allow us at the moment to make further suppositions about it. In any case, it is interesting to note that the presence in Vitelli's collection of a portrait of Queen Elizabeth is a sign of his desire, albeit perhaps momentary, to pay his personal homage to the English sovereign.

\section{BIBLIOGRAPHY}

\section{Archival Sources}

Florence, Archivio di Stato

Rondinelli Vitelli, b. 1

Mediceo del Principato (MdP), vols 649, 650, 651, 1175, 4903

\section{Florence, Biblioteca Moreniana}

fondo Moreni, MS 28, Lorenzo Borghesi, Vita di Chiappino Vitelli

San Giustino, Archivio Bufalini

degli Azzi, b. 140 


\section{Secondary Works}

Acidini, Cristina, Taddeo e Federico Zuccari fratelli pittori del Cinquecento (Milan: Jandi Sapi, 1998), vol. 2

Arfaioli, Maurizio, 'Alla destra del Duca: la figura di Chiappino Vitelli nel contesto degli affreschi vasariani del Salone dei Cinquecento', Mitteilungen des Kunsthistorischen Institutes in Florenz, 51 (2008), 271-78

Arfaioli, Maurizio, 'Sofonisba Anguissola, Francesco de' Medici and Chiappino Vitelli: a lady-in-waiting, a prince and a general at the Spanish court', in The Grand Ducal Medici and their Archive 1537-1743, ed. by Alesio Assonitis, Brian Sandberg (London: Brepols Publishers, 2016), pp. 117-22

Baglione, Giovanni, Le vite de pittori, scultori et architetti. Dal Pontificato di Gregorio XIII del 1572 in fino a' tempi di Papa Urbano VIII nel 1642 (Rome: Andrea Fei, 1642)

Bajetta, Carlo Maria, 'Elizabeth I, Chiappino Vitelli and Federico Zuccaro', Notes and Queries, 60 (2013), 386-91

Bajetta, Carlo Maria, Elizabeth I's Italian Letters (New York: Palgrave Macmillan, 2017)

Borghini, Raffaello, Il Riposo (Florence: Marescotti, 1584)

Bunes Ibarra, Miguel Ángel de - Madroñal, Abraham, 'Una carta jocosa inédita de Francisco de Aldana y nuevos datos parasu biografía', Revista de filología Española, 90, no. 1 (2010), 9-45

Calonaci, Stefano, 'Cosimo I e la corte: percorsi storiografici e alcune riflessioni', Annali Di Storia Di Firenze, 9 (2015), pp. 57-76

Ciliberti, Galliano, Il Teatro degli Accademici Illuminati di Città di Castello (Firenze: Olschki, 1995)

Contini, Alessandra, 'Aspects of Medicean Diplomacy in the sixteenth century', Politics and Diplomacy in Early Moderm Italy. The Structure of Diplomatic Practice, 1450-1800, ed. by Daniela Frigo (Cambridge: Cambridge University Press, 2000), pp. 49-94

Crinò, Anna Maria, 'Documenti relativi a Pietro da Cortona, Ciro Ferri, Pietro Tacca, Pier Maria Baldi, Il Guercino e Federigo Zuccaro', Rivista d'arte, 34 (1959), $151-57$

Crinò, Anna Maria, 'Un altro memoriale inedito di Roberto Ridolfi', La Biblioflía, 57 (1955), 148-55

Laugier, Cesare de, 'Chiappino Vitelli', Giornale militare italiano, 3(1846), 17-19

Lettenhove, Constantin Kervin de, Relations Politiques des Pays-Bas Et de l'Angleterre, Sous le Règne de Philippe II (Brussels: Hayez, 1886), vol. 5

Edwards, Francis, The Marvellous Chance: Thomas Howard, fourth duke of Norfolk and the Ridolphi plot, 1570-1572 (London: Hart-Davies, 1968)

Gamberini, Diletta, 'La "concucia nana" di Federico Zuccari: critica d'arte in versi all'ombra del Giudizio Universale per la cupola di Santa Maria del Fiore', Mitteilungen des Kunsthistorischen Institutes in Florenz, 59, no. 3 (2017), 362-87

Gere, John Arthur, Philip Pouncey, Italian drawings in the British Museum, Artists working in Rome (London: Trustees of the British Museum, 1983) 
Goldring, Elizabeth, 'An Important Early Picture Collection: The Earl of Pembroke's 1561/62 Inventory and the Provenance of Holbein's 'Christina of Denmark', Burlington Magazine, 144 (2002), pp. 157-60

Goldring, Elizabeth, 'Portraits of Queen Elizabeth I and the Earl of Leicester for Kenilworth Castle', Burlington Magazine, 147 (2005), 654-60

Kamen, Henry, Il duca d'Alba (Torino: Utet, 2006)

Lazzari, Francesco Ignazio, Il trionfo della religione cattolica nell'Inghilterra opera scenica del signor Francesco Ignatio Lazzari Accademico Illuminato di Città di Castello (Forlì: Saporetti, 1669)

Lorenzoni, Martina, 'Federico Zuccari e il Breviario Grimani', Saggi e memorie di storia dell'arte, 39 (2015), 7-29, 238

Mavilla, Francesca, "'Sua signoria è qua in molta buona riputatione con ciascuno": Chiappino Vitelli e i fratelli Guicciardini', Horti Hesperidum, 8, no. 1 (2018), $321-48$

Mavilla, Francesca, 'Committenti e collezionisti tra l'Italia e le Fiandre, il ruolo di Paolo e Chiappino Vitelli nel contesto artistico e culturale del Cinquecento' (unpublished doctoral dissertation, Università degli Studi di Perugia, 2016)

Nievas Rojas, Adalid, Nuevos datos para la biografía de Francisco de Aldana (II). Primera etapa en Flandes (1567-1571)', Boletín de la Real Academia Española, 100, no. 321 (2020), 147-206

Parker, Geoffrey, 'The Place of Tudor England in the Messianic Vision of Philip II of Spain: The Prothero Lecture', Transactions of Royal Historical Society, 12 (2002), $167-221$

Promis, Carlo, Biografie di ingegneri militari italiani dal secolo XIV alla metà del XVII (Torino: Fratelli Bocca, 1874)

Ramsay, George Daniel, The Queen's Merchants and the Revolt of the Netherlands (Manchester: Manchester University Press, 1986)

Sewter, Albert Charles, 'Queen Elizabeth at Kenilworth', Burlington Magazine, 76, no. 444 (1940), 73-76

Strada, Famiano, Histoire de la guerre de Flandre (Paris: Antoine de Sommaville, 1651) Strong, Roy Colin, 'Federigo Zuccaro's Visit to England in 1575', Journal of the Warburg and Courtauld Institutes, 22 (1959), 359-60

Van den Heuvel, Charles, "Papiere Bolwerken" de introductie van de Italiaanse steden vestingbouw in de Nederlanden (1540-1609) en het gebruik van tekeningen (Alphen aan den Rijn: Canaletto, 1991)

Mander, Karel van, Le vite degli illustri pittori fiamminghi, olandesi e tedeschi, ed. by Ricardo de Mambro Santos (Sant'Oreste: Apeiron Editori, 2000)

Wyatt, Michael, The Italian encounter with Tudor England: a cultural politics of translation (Cambridge: Cambridge University Press, 2005)

Francesca Mavilla - graduated in 2012 (MSc), in 2016 became an archivist at the State Archives of Perugia. In 2017 obtained her PhD at University of Perugia and, from August to December 2018, was a post-doctoral fellow at the Dutch University 
Institute of Art History in Florence. Her studies focus mainly on exchanges between Italian and Flemish culture in the second half of the sixteenth century and on the links with Flanders of Farnese and Medici courts. In 2020, she was research fellow at University of Perugia. Currently, she is collaborating with Regione Umbria as external scientific consultant for the 500th anniversary of Raffaello Sanzio's death initiatives; e-mail: mavilla.francesca@gmail.com 